\title{
Iron acquisition during growth in an iron- deficient medium by Rhizobium sp. isolated from Cicer arietinum
}

\author{
Nupur Roy, ${ }^{1}$ P. Bhattacharyya ${ }^{2}$ and P. K. Chakrabartty ${ }^{1}$
}

Author for correspondence: P. K. Chakrabartty.

Departments of

Microbiology ${ }^{1}$ and of

Chemistry2, Bose Institute, P-

$1 / 12$, CIT Scheme VII M,

Calcutta 700054, India

\begin{abstract}
A catechol-type siderophore was produced extracellularly by Rhizobium sp. strain BICC 651 isolated from Cicer arietinum during growth in iron-deficient medium. Production of the siderophore was fully repressed in the presence of $50 \mu \mathrm{M} \mathrm{Fe}^{3+}$. The siderophore was purified and characterized as containing 2,3dihydroxybenzoic acid (DHBA) as the core compound and threonine as its conjugate. The siderophore was able to reverse growth inhibition of the strain induced by ethylenediamine-di(o-hydroxyphenyl-acetic acid) (EDDA). A highaffinity iron-transport system capable of transporting ${ }^{59} \mathrm{Fe}$-siderophore complex was also induced in Rhizobium BICC 651 grown under iron deficiency. Two protein bands of molecular masses 76 and $82 \mathrm{kDa}$ were also inductively synthesized in the outer membrane of the cells. A partially purified ferrireductase enzyme of Rhizobium BICC 651 catalysed reductive release of iron from the ferric chelate of DHBA. The enzyme had a $K_{m}$ of $0.3 \mathrm{mM}$ for ferriDHBA, was constitutive in nature, and was present in the cytosolic fraction during growth under both iron-deficient and iron-sufficient conditions. The enzyme occurred as two isoenzymes with $R_{F}$ values of 0.48 and 0.51 , respectively, in a nondenaturing polyacrylamide gel.
\end{abstract}

Keywords: Rhizobium, siderophore, iron transport, outer membrane proteins, ferrireductase

\section{INTRODUCTION}

Iron-containing proteins figure prominently in symbiotic nitrogen fixing systems. The symbiotic bacteria need an adequate supply of iron for the synthesis of nitrogenase, the haem moiety of leghaemoglobin and many other ironcontaining compounds such as ferredoxin, hydrogenase and cytochromes. Although iron is abundantly present in the soil, it forms extremely insoluble oxides and oxyhydroxides under aerobic conditions and neutral $\mathrm{pH}$. Under these conditions bacteria synthesize high-affinity ferric-specific ligands, siderophores, and their cognate membrane receptors (Neilands, 1989) to acquire iron. Assimilation of iron from ferri-siderophore complex, once it has been transported to the cytoplasm via specific receptors, involves the reduction of $\mathrm{Fe}^{3+}$ to $\mathrm{Fe}^{2+}$ for which the siderophore has no affinity (Crichton \& Charloteaux-Wauters, 1987). Siderophores in rhizobia appear to be strain-specific (Guerinot, 1991) and represent

Abbreviations: CAS, chrome azurol S; DHBA, 2,3-dihydroxybenzoic acid; EDDA, ethylenediamine-di(o-hydroxyphenyl-acetic acid); NTA, nitrilotriacetate; OM, outer membrane. a wide range of structures (Guerinot, 1991; Carson $e t$ al., 1992).

In this paper, we describe the identification and characterization of a catechol-type of siderophore produced by Rhizobium sp. strain BICC 651 isolated from Cicer arietinum in response to iron starvation and the membrane proteins synthesized under this condition. The enzyme ferrireductase which is responsible for reduction of $\mathrm{Fe}^{3+}$ to $\mathrm{Fe}^{2+}$ has also been partially characterized.

\section{METHODS}

Organisms, media and growth conditions. The strains used in this study are listed in Table 1. All strains were maintained on yeast extract mannitol slopes (Vincent, 1970). For studies on siderophore production, the bacteria were grown in complete medium (Modi et al., 1985) with the following composition $\left(\mathrm{g} \mathrm{l}^{-1}\right): \mathrm{K}_{2} \mathrm{HPO}_{4}, 0.5 ; \mathrm{MgSO}_{4} .7 \mathrm{H}_{2} \mathrm{O}, 0.4 ; \mathrm{NaCl}, 0 \cdot 1$; mannitol, 10; glutamine, 1 ; and $\mathrm{NH}_{4} \mathrm{NO}_{3}, 1$. The medium was deferrated by treatment with 8 -hydroxyquinoline following the method of Rosenberg (1979). During inoculation the initial $\mathrm{OD}_{590}$ of the culture was adjusted to $0 \cdot 001$. The bacteria were subcultured three times consecutively in deferrated complete medium to reduce their internal ferric iron stores before use as inoculum. 
Table 1. Bacterial strains used in this study

\begin{tabular}{|llc|}
\hline Strain & Source* & $\begin{array}{c}\text { Siderophore } \\
\text { productiont }\end{array}$ \\
\hline Rbizobium sp. (Cicer arietinum) & & \\
BICC 651 & BI & + \\
BICC 619 & BI & - \\
BICC 620 & BI & - \\
BICC 630 & BI & - \\
BICC 631 & BI & - \\
BICC 632 & BI & + \\
BICC 637 & BI & + \\
TAL 621 & NifTAL & - \\
Rbizobium meliloti & & - \\
BICC 604 & BI & - \\
CC 169 & CSIRO & - \\
SU 47 & CSIRO & - \\
Rbizobium sp. (Aeschynomene aspera) & & - \\
BICC 608 & BI & - \\
Rbizobium leguminosarum bv. viciae & & - \\
BICC 635 & BI & - \\
Bradyrbizobium sp. (Cicer arietinum) & & - \\
27 A 14 & Nitragin & - \\
IC 76 & ICRISAT & - \\
IC 59 & ICRISAT & - \\
IC 2099 & ICRISAT & - \\
TAL 385 & NifTAL & - \\
TAL 619 & NifTAL & - \\
TAL 1012 & NifTAL & - \\
Ca 2 & HAU & - \\
Bradyrbizobium sp. (Cajanus cajan) & & - \\
BICC 616 & BI & - \\
\hline BI & & - \\
\hline
\end{tabular}

* BI, Bose Institute, Calcutta, India; NifTAL, NifTAL Project and MIRCEN, University of Hawaii, Paia, Hawaii, USA; CSIRO, Division of Plant Industry, CSIRO, Canberra, Australia; Nitragin, Nitragin Company, Milwaukee, Wisconsin, USA; ICRISAT, ICRISAT, Patancheru, P.O., A.P., India; HAU, Haryana Agricultural University, Haryana, India.

++ , Siderophore produced; - , no siderophore produced.

All glassware was previously washed in $6 \mathrm{M} \mathrm{HCl}$ and rinsed several times in deionized water to free it of iron. Iron was supplemented in the medium from a freshly prepared membrane-filtered $50 \mathrm{mM} \mathrm{FeCl}_{3}$ solution when required. The cultures were incubated at $28^{\circ} \mathrm{C}$ on a rotary shaker (128 r.p.m.). Growth of the bacteria was monitored by measuring the $\mathrm{OD}_{590}$ of the culture at regular intervals.

Estimation of iron. Iron was estimated by a colorimetric method using chromogen ferrozine (Stookey, 1970) with ferrous ammonium sulphate as the standard. The lower limit of sensitivity of the ferrozine method was about $0.3 \mu \mathrm{M}$. Complete medium routinely contained about $0.5 \mu \mathrm{M}$ iron before deferration and was below the level of detection by the ferrozine method after deferration with hydroxyquinoline.

Siderophore assays. Four different chemical assays were used to detect siderophore activity in the medium. The chrome azurol S (CAS) assay was performed as described by Schwyn \& Neilands (1987). This assay detects all siderophores irrespective of their chemical nature. The method of Arnow (1937) or that of Rioux et al. (1983) was used to detect catechol-type siderophores using 2,3-dihydroxybenzoic acid (DHBA) as the standard. Hydroxamate-type siderophore was assayed by the method of Csáky (1948). Phenolic compounds were detected by reaction with the Hathway reagent (Hathway, 1969).

Bioassays were performed in liquid complete medium to which ethylenediamine-di(o-hydroxyphenyl-acetic acid) (EDDA) was added to a final concentration of $4 \mathrm{mg} \mathrm{ml}^{-1}$ to make the medium iron-restricted by chelating any adventitious iron. This caused severe growth inhibition of strain BICC 651. Reversal of EDDA-induced growth inhibition by the addition of siderophore isolated from the iron-deficient homologous culture was used as the criterion of bioactivity of the siderophore. Siderophore production in solid medium was detected on plates containing complete medium mixed with CAS reagent. An orange halo surrounding the growth of bacterial colonies (Schwyn \& Neilands, 1987) indicated siderophore production.

Isolation and purification of siderophore. Siderophore was isolated from culture filtrate after adjustment to $\mathrm{pH} 2.0$ with $1 \mathrm{M} \mathrm{HCl}$. This was extracted three times with an equal volume of ethyl acetate and then dried in vacuo. The extracted siderophore was separated by thin-layer chromatography (TLC). Characteristic bands of the siderophore fluorescing blue under UV light were scraped off the TLC plates and then extracted with ethanol.

Thin-layer, paper and high-performance liquid chromatography. Separation of siderophores by TLC was done on silica gel $G$ plates using the solvent system dichloromethane/ methanol $(3: 2, v / v)$. Ascending paper chromatography on Whatman $1 \mathrm{MM}$ paper was used for separation of siderophores or their amino acid conjugate using the solvent system butanol/water/acetic acid (12:5:3, by vol.). HPLC (Waters, Millipore) was also used for identification of amino acids following acid hydrolysis of the siderophore. Siderophores were detected on chromatograms by spraying with CAS solution, which produced a purple spot against a blue background (Schwyn \& Neilands, 1987). Amino acids were detected on paper chromatograms with $0.4 \%$ ninhydrin in acetone as the spray reagent.

Spectroscopic methods. Ultraviolet spectra were recorded on a Shimadzu model UV 240 spectrophotometer. Infrared spectra were recorded on a Shimadzu IR 408 spectrophotometer. Mass spectra were obtained with an AEI MS 30 mass spectrometer operated at an ionization potential of $70 \mathrm{eV}$ and ion source temperature of $100-150^{\circ} \mathrm{C}$.

Transport experiments. The uptake buffer $[50 \mathrm{mM}$ potassium phosphate, $\mathrm{pH} 7 \cdot 0,0.2 \mathrm{mM}$ nitrilotriacetate (NTA)], with or without a carbon source such as $0.025 \%$ sodium succinate or $0.025 \%$ mannitol, was made iron-free by the 8 -hydroxyquinoline extraction method (Rosenberg, 1979).

${ }^{59} \mathrm{FeCl}_{3}$ [20 nmol in $16 \mu \mathrm{l}$; sp. act. $7 \cdot 4 \mathrm{Ci}(273.8 \mathrm{GBq}) \mathrm{g}^{-1}, 1.5$ $\mathrm{mCi} \mathrm{ml}^{-1}$ ] was initially mixed with $180 \mathrm{nmol}$ unlabelled $\mathrm{FeCl}_{3}$ in $144 \mu \mathrm{l} 0 \cdot 1 \mathrm{M} \mathrm{HCl}$ to reduce the specific activity to $0.74 \mathrm{Ci} \mathrm{g}^{-1}$. A portion of this mixture $\left(20 \mathrm{nmol}^{59} \mathrm{FeCl}_{3}\right)$ was added to 200 nmol siderophore (based on molar concentration of 2,3DHBA content) and then incubated in the dark on ice for $24 \mathrm{~h}$ to allow a stable complex to form.

Rbizobium sp. strain BICC 651 was grown to mid-exponential phase $\left(\mathrm{OD}_{590}=1.0\right)$ in a medium containing $\left(\mathrm{gl}^{-1}\right): \mathrm{K}_{2} \mathrm{HPO}_{4}$, $0 \cdot 5 ; \mathrm{MgSO}_{4} .7 \mathrm{H}_{2} \mathrm{O}, 0 \cdot 4 ; \mathrm{NaCl}, 0 \cdot 1 ;$ glutamine, $0.5 ; \mathrm{NH}_{4} \mathrm{NO}_{3}, 1$. Succinate or mannitol at $5 \mathrm{~g} \mathrm{l}^{-1}$ was used as carbon source. Cells from $1 \mathrm{ml}$ culture were collected by centrifugation at $10000 \mathrm{~g}$ for $10 \mathrm{~min}$ and washed with uptake buffer. The cells were then resuspended in $2 \mathrm{ml}$ fresh uptake buffer and kept at $32{ }^{\circ} \mathrm{C}$ for 
$10 \mathrm{~min}$ for temperature equilibration. To this cell suspension ${ }^{59} \mathrm{FeCl}_{3}$-siderophore complex containing $20 \mathrm{nmol}{ }^{59} \mathrm{Fe}$ was added. The assay mixture was kept at $32{ }^{\circ} \mathrm{C}$ in a shaker incubator. Samples of $200 \mu \mathrm{l}$ were withdrawn from the uptake mixture at intervals, added to $10 \mathrm{ml}$ pre-chilled wash buffer (50 $\mathrm{mM}$ potassium phosphate buffer, $\mathrm{pH} 6.8$ containing $0.4 \mathrm{mM}$ NTA) and filtered through membrane filters $(0.45 \mu \mathrm{m}$; Millipore). The filter was washed with another $10 \mathrm{ml}$ of wash buffer, dried and then counted in a liquid scintillation system (Beckman LS $5000 \mathrm{CE}$ ) using cocktail ' $\mathrm{O}$ ' (Spectrochem) scintillation fluid. Blanks were prepared for each experiment by the same procedure except that cells were omitted and the assay volumes were adjusted with uptake buffer.

Isolation of outer-membrane proteins. Outer membranes (OM) were prepared by the Sarkosyl solubilization method of Filip et al. (1973). Washed bacterial pellets containing $1 \cdot 2 \times 10^{11}$ cells were suspended in $15 \mathrm{ml}$ HEPES buffer $(10 \mathrm{mM}, \mathrm{pH} 7 \cdot 0)$, placed in an ice bath and broken by $6 \times 30 \mathrm{~s}$ pulses of sonication at $90 \mathrm{~W}$ using the standard probe of a Labsonic sonicator (Braun) with $1 \mathrm{~min}$ intervals for cooling. Unbroken cells were removed by centrifugation at $10000 \mathrm{~g}$ for $10 \mathrm{~min}$. The supernatant was then centrifuged at $100000 \mathrm{~g}$ and $4{ }^{\circ} \mathrm{C}$ for $1 \mathrm{~h}$ and the crude envelope pellet obtained was treated with Sarkosyl $(N$ lauroylsarcosine, sodium salt; Sigma; final concentration $0.5 \%$, $\mathrm{w} / \mathrm{v})$ in HEPES buffer $(10 \mathrm{mM}, \mathrm{pH} 7 \cdot 0)$. After incubation for 30 min at room temperature, the mixture was centrifuged at $100000 \mathrm{~g}$ for $1 \mathrm{~h}$. The OM pellet was washed twice in distilled water and stored at $-20^{\circ} \mathrm{C}$. The protein content of $\mathrm{OM}$ samples was determined by the modified Lowry method (Markwell et al., 1978).

SDSPAGE. Electrophoresis was performed on $7.5 \%(\mathrm{w} / \mathrm{v})$ acrylamide gels (Laemmli, 1970) in a slab-gel apparatus (ATTO, Japan). An OM sample was mixed with an equal volume of sample buffer $[10 \mathrm{mM}$ Tris $/ \mathrm{HCl}(\mathrm{pH} \mathrm{6.8)}, 4 \%$ (w/v) SDS, $20 \%,(\mathrm{v} / \mathrm{v})$ glycerol and $0.002 \%(\mathrm{v} / \mathrm{v}) \beta$-mercaptoethanol] and boiled at $100^{\circ} \mathrm{C}$ for $20 \mathrm{~min}$ prior to electrophoresis. Gels were stained with Coomassie Brilliant Blue R-250 in methanol/ water/acetic acid (50:40:10, by vol.) and destained in water/ acetic acid/methanol $(87 \cdot 5: 7 \cdot 5: 5$, by vol. $)$.

Assay of ferrireductase. The cells were grown to midexponential phase in the presence or absence of $50 \mu \mathrm{M} \mathrm{FeCl}_{3}$ and were harvested by centrifugation. They were lysed by sonication as before, using the standard probe of a Labsonic 2000 sonicator. The soluble fraction of the cell homogenate was separated from the membrane fraction by centrifugation at $100000 \mathrm{~g}$. The supernatant was fractionally precipitated at $40-80 \%$ ammonium sulphate saturation and the protein pellet obtained was solubilized in $0 \cdot 1 \mathrm{M}$ Tris $/ \mathrm{HCl}, \mathrm{pH} 7 \cdot 4$. This was dialysed against the same buffer and was used as the source of the enzyme. The enzyme was assayed following the method of Dailey \& Lascelles (1977) in $1 \mathrm{ml}$ assay mixture containing $1 \mathrm{M}$ Tris/ $\mathrm{HCl}$ buffer, pH 7·4, ferri-DHBA complex $(0 \cdot 16 \mathrm{mM})$, NADH $(0 \cdot 16 \mathrm{mM})$, FMN $(0.015 \mathrm{mM}), \mathrm{MgCl}_{2}(1 \mathrm{mM})$ and ferrozine $(0.8 \mathrm{mM})$. The ferrous ion produced by the activity of the enzyme was chelated with ferrozine. Iron reduction was monitored by measuring the absorption of the ferrozine-ferrous iron complex at $562 \mathrm{~nm}$ in a spectrophotometer against a reference cuvette which contained the complete assay mixture without the enzyme. The specific activity of the enzyme was expressed as nmol $\mathrm{Fe}^{2+}$-ferrozine formed $\mathrm{min}^{-1}$ (mg protein) ${ }^{-1}$. The substrate ferri-DHBA was prepared by mixing DHBA with $\mathrm{FeCl}_{3}$ and incubating for $24 \mathrm{~h}$ on ice in the dark. The gel electrophoresis profile of the enzyme ferrireductase was ascertained by its activity staining. A partially-purified enzyme preparation obtained by ammonium sulphate fractionation was subjected to electrophoresis in native polyacrylamide $(10 \%, w / v)$. The running buffer used was
0.025 M Tris/0.192 M glycine, $\mathrm{pH} 8 \cdot 3$. After electrophoresis the gel was incubated for $20-30 \mathrm{~min}$ in the staining solution as described by Moody \& Dailey (1983). Distinct purple bands appeared against a yellowish-pink background. The background, however, became purple in a short time and the bands were indistinguishable from it. Protein was estimated by the dye binding method of Bradford (1976).

\section{RESULTS}

\section{Siderophore production by strains of Rhizobium and Bradyrhizobium}

Initially, all the strains were cultured in deferrated complete medium and the culture filtrates were examined for the presence of siderophore by mixing with CAS reagent. The results (Table 1) show that of the 13 different strains of Rbizobium only four, BICC 632, BICC 637, BICC 651 and BICC 635, produced siderophore. Among the nine Bradyrbizobium strains examined, only BICC 616 produced siderophore.

In paper chromatography, Rhizobium strains BICC 632 and BICC 651 produced only one band of siderophore each, with $R_{F}$ values of $0 \cdot 82$ and $0 \cdot 80$, respectively. On the other hand, Rhizobium BICC 637 produced siderophore which separated into three bands, the major one with an $R_{F}$ value of 0.40 and two minor ones with $R_{F}$ values of $0 \cdot 19$ and $0 \cdot 90$. R. leguminosarum bv. viciae BICC 635 also produced siderophores which separated into two bands; the major band had an $R_{F}$ value of 0.23 and the minor one an $R_{F}$ value of $0 \cdot 13$. Further studies were conducted with strain BICC 651 for characterization of its iron acquisition system since the strain produced only a single kind of siderophore at a high concentration.

\section{Growth and siderophore production in deferrated complete medium}

In deferrated complete medium strain BICC 651 had a lag period of $7 \mathrm{~h}$ and the culture reached the stationary phase of growth at $40 \mathrm{~h}$, when the $\mathrm{OD}_{590}$ was slightly more than $2 \cdot 0$. During growth the level of siderophore in the culture filtrate increased progressively, paralleling the increase in $\mathrm{OD}_{590}$, and reached its peak at the late-exponential phase $(30 \mathrm{~h})$. The level of siderophore then declined sharply, although the $\mathrm{OD}_{590}$ of the culture remained constant until $80 \mathrm{~h}$ (Fig. 1). During the peak, more than $110 \mathrm{nmol}$ equivalent of DHBA was produced (ml culture $)^{-1}$.

\section{Effect of iron and carbon source on growth and siderophore production}

In the medium without iron supplement the biomass yield was the lowest $\left(\mathrm{OD}_{590}=2 \cdot 0\right)$ and the yield increased with increasing concentrations of iron up to $50 \mu \mathrm{M} \mathrm{FeCl}_{3}$ (Fig. 2 ). Siderophore production in the medium without iron supplement was low $(110 \mathrm{nmol}$ equivalent of DHBA $\mathrm{ml}^{-1}$ ) relative to that in the medium with $0.1 \mu \mathrm{M} \mathrm{FeCl}_{3}$, where maximum production of $170 \mathrm{nmol}$ equivalent of DHBA ml-1 was recorded. With increasing concentrations of iron the level of siderophore produced decreased gradually, and at $50 \mu \mathrm{M} \mathrm{FeCl}_{3}$ the siderophore was almost undetectable in the culture filtrate (Fig. 2). 


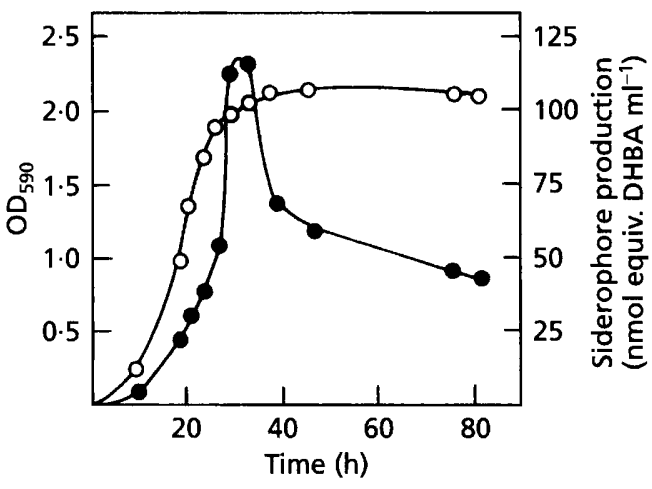

Fig. 1. Growth and siderophore production by Rhizobium strain BICC 651. Growth $(O)$ in deferrated complete medium was monitored by measuring $\mathrm{OD}_{590}$, and siderophore production (O) was assayed by Arnow's method using DHBA as standard. The data shown are representative curves from replicate experiments.

Table 2. Effect of different carbon sources on growth and siderophore production by Rhizobium strain BICC 651

Carbon sources were used at a concentration of $10 \mathrm{~g} \mathrm{l}^{-1}$. The data shown are means of duplicate experiments. Deviation of the individual observations from the mean was $8 \%$ or less.

\begin{tabular}{|lcc|}
\hline Carbon source & $\begin{array}{c}\text { Growth } \\
\left.\mathbf{( O D}_{590}\right)\end{array}$ & $\begin{array}{c}\text { Siderophore } \\
\text { production } \\
\text { [nmol equiv. of } \\
\text { DHBA (ml }\end{array}$ \\
& & culture filtrate) $)^{-1}$ ] \\
\hline Control & $0 \cdot 01$ & 0 \\
Glucose & $2 \cdot 41$ & 94 \\
Mannitol & $2 \cdot 17$ & 170 \\
Rhamnose & $2 \cdot 12$ & 128 \\
Arabinose & $1 \cdot 57$ & 30 \\
Glycerol & $2 \cdot 45$ & 148 \\
Maltose & $2 \cdot 45$ & 134 \\
Sodium pyruvate & $1 \cdot 56$ & 240 \\
Sodium succinate & $1 \cdot 19$ & 320 \\
Sodium malate & $2 \cdot 26$ & 11 \\
\hline
\end{tabular}

No growth or siderophore production occurred in a control experiment in the basal medium without any carbon source (Table 2). Glucose, mannitol, rhamnose, glycerol, malate or maltose as carbon source supported better growth of strain BICC 651 than the other carbon sources. Growth on malate, however, resulted in very little siderophore production [11 nmol equivalent of DHBA (ml culture filtrate) $\left.{ }^{-1}\right]$. Growth on arabinose, pyruvate or succinate was comparatively low. However, highest siderophore production $(320 \mathrm{nmol}$ equivalent of DHBA ml $\mathrm{m}^{-1}$ ) was achieved with succinate, followed by pyruvate $\left(240 \mathrm{nmol}\right.$ equivalent of $\left.\mathrm{DHBA} \mathrm{ml}{ }^{-1}\right)$ as the carbon source (Table 2).

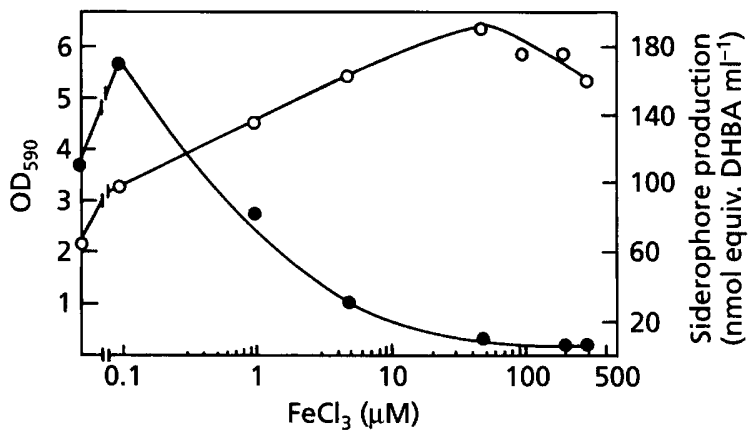

Fig. 2. Effect of increasing concentrations of iron on growth and siderophore production by Rhizobium strain BICC 651 . Different concentrations of $\mathrm{FeCl}_{3}$ were added in deferrated complete medium and the cultures were incubated for $30 \mathrm{~h}$ on a shaker at $28^{\circ} \mathrm{C}$. Cell yield was measured by monitoring $O D_{590}$ $(O)$, and siderophore production (O) was measured by Arnow's method using DHBA as standard. The data shown are representative curves from replicate experiments.

\section{Isolation, purification and characterization of the siderophore}

To characterize the siderophore produced by strain BICC 651 the compound was isolated and purified. At $30 \mathrm{~h}$ of growth, strain BICC 651 yielded almost $82 \mathrm{nmol}$ equivalent of DHBA ( $\mathrm{ml}$ culture $)^{-1}$. The ethyl acetate extract was chromatographed on TLC plates of silica gel along with several reference compounds. The extracted compound had an $R_{F}$ value very close to that of DHBA (data not shown).

Siderophores usually consist of a core compound to which one or two amino acids remain conjugated. To examine the siderophore of strain BICC 651, the extract was run on a TLC plate of silica gel and sprayed with ninhydrin. This yielded a characteristic purple spot at the location coinciding with that of the siderophore. For separation of the conjugated amino acids from the core compound, the purified siderophore was hydrolysed with acid; the hydrolysate was dissolved in water and extracted with ethyl acetate. The organic phase contained the core compound, while the aqueous phase contained the free amino acids as revealed by spot tests of the two fractions with $\mathrm{FeCl}_{3}$ and with ninhydrin. The dried organic phase from ethyl acetate extractions was characterized by mass spectrometry. The mass spectrum of the compound showed a molecular ion peak at $\mathrm{M}^{+} 154$. The other significant peaks were at $\mathrm{m} / \mathrm{z} 136,108$ and 80 . The peak $m / z 136$ obtained from the molecular ion peak $\left(\mathrm{M}^{+} 154\right)$ indicated loss of mass 18 from the molecular ion peak which is characteristic of o-hydroxybenzoic acid (Silverstein et al., 1981).

To confirm the identity of the core compound of the siderophore UV and IR spectra were recorded and compared to that of authentic 2,3-DHBA. UV spectra of both compounds showed three peaks with $\lambda_{\text {max }}$ in ethanol at 315,250 and $210 \mathrm{~nm}$. The IR spectrum of the core compound of the siderophore showed absorption bands 


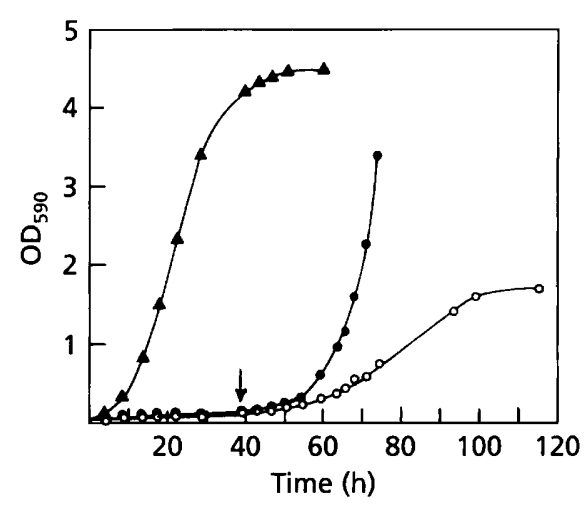

Fig. 3. Reversal of EDDA-induced growth inhibition of Rhizobium strain BICC 651 by siderophore isolated from a homologous culture. Growth of the strain was monitored by measuring $\mathrm{OD}_{590}$ in complete medium ( $\mathbf{A}$ ) as control, in medium with the addition of EDDA to a final concentration of $4 \mathrm{mg} \mathrm{ml}^{-1}(O)$, or in the medium plus EDDA to which purified siderophore from strain BICC 651 was added to a concentration of $8.2 \mathrm{nmol}$ equivalent of DHBA ml $\mathrm{I}^{-1}$ at $40 \mathrm{~h}$ of growth (-). The data shown are representative curves from replicate experiments.

at $v \mathrm{KBr}_{\max } 3500,1720$ and $1600 \mathrm{~cm}^{-1}$. These spectra were very similar to that of the authentic DHBA and were essentially superimposable.

The aqueous phase after ethyl acetate extraction of the hydrolysate was lyophilized to dryness and then chromatographed together with standard amino acids on paper. Only one band was identified in the chromatogram after spraying with ninhydrin. The band had an $R_{F}$ value of $0 \cdot 30$, very close to that of threonine. In a separate experiment, co-chromatography of the amino acid from siderophore with threonine yielded a single band (data not shown). The identity of the amino acid was further confirmed to be threonine by the fact that its retention time on HPLC was identical to that of an authentic threonine sample: $6.9 \mathrm{~min}$. The concentration of threonine was estimated from the peak height in HPLC by comparing it with those of known quantities of threonine. The molecular ratio of threonine to DHBA in the siderophore was calculated to be almost two.

\section{Reversal of EDDA-imposed growth inhibition by siderophore}

To assess if the isolated siderophore was biologically active and could provide iron to the organism in an ironpoor environment, the reversal of EDDA-imposed growth inhibition by added siderophore was investigated. Strain BICC 651 exhibited a characteristic growth curve in complete medium from which the generation time was calculated to be $6 \mathrm{~h}$ (Fig. 3). The culture reached its stationary phase at about $40 \mathrm{~h}$, when maximum cell yield was almost $\mathrm{OD}_{590} 4 \cdot 5$. Addition of EDDA to this medium caused the lag period to extend to more than $50 \mathrm{~h}$ and the generation time increased to $17 \mathrm{~h}$. Maximum cell yield was $\mathrm{OD}_{590} 1 \cdot 5$, or only one-third of the control culture without addition of EDDA. However, when purified siderophore from strain BICC $651(8 \cdot 2 \mu \mathrm{mol}$ equivalent of DHBA) was added to the EDDA-inhibited culture at $40 \mathrm{~h}$, growth of the bacterium resumed with a generation time comparable to that of the control culture with equivalent cell yield.

Isolated siderophore was also able to stimulate the growth of Rhizobium strain BICC 632 and Bradyrhizobium strain TAL 1012 in the bioassays. The degree of stimulation, however, varied from strain to strain.

\section{Siderophore-mediated iron uptake}

Iron uptake was induced when the bacterial cells were grown under iron stress (Fig. 4). With succinate-grown cells the uptake was linear for at least $120 \mathrm{~min}$. In cells grown in presence of $50 \mu \mathrm{M} \mathrm{FeCl}_{3}$, the active uptake system for iron was absent, as evident from the fact that ${ }^{59} \mathrm{Fe}$ uptake from an iron-siderophore complex did not occur (Fig. 4). Transport of free iron in the uptake buffer was eliminated by the addition of $0.2 \mathrm{mM}$ NTA. This caused negligible uptake of uncomplexed ${ }^{59} \mathrm{Fe}^{3+}$ by the induced cells (Fig. 4). For mannitol-grown cells, siderophore-mediated uptake of iron appeared biphasic, with an initial rapid uptake and ensuing slower uptake (Fig. 4, inset). The rate of slow uptake in mannitol-grown cells was very close to the uptake rate of succinate grown cells. The rate was not significantly influenced by the presence or absence of a carbon source in the uptake buffer for 30 min (Fig. 4, inset).

\section{Characterization of outer membrane proteins}

To examine the differences between the protein profiles of OMs isolated from bacteria grown in absence or presence of $50 \mu \mathrm{M} \mathrm{FeCl}_{3}, \mathrm{SDS}-\mathrm{PAGE}$ of the OM proteins was carried out. In the cells grown in iron-deficient conditions $\left(0.5 \mu \mathrm{M} \mathrm{FeCl}_{3}\right)$ three prominent high-molecular-mass peptide bands, of 91,82 and $76 \mathrm{kDa}$, were present, while the cells grown in iron-sufficient conditions $(50 \mu \mathrm{M} \mathrm{FeCl})$ showed only a single band of $91 \mathrm{kDa}$ in the highmolecular-mass range (Fig. 5).

\section{Ferrireductase activity in Rhizobium strain BICC 651}

In the microbial iron-uptake assimilation process, iron must be released from ferri-siderophore after its uptake. Release takes advantage of the fact that siderophores have only weak affinity for $\mathrm{Fe}^{2+}$. Therefore, the $\mathrm{Fe}^{3+}$ siderophore complex is acted on by the ferrireductase enzyme to release $\mathrm{Fe}^{2+}$. A partially purified enzyme fraction was obtained from strain BICC 651 that catalysed reductive release of iron from the ferric chelate of DHBA (ferri-DHBA). Under the assay conditions the enzyme had an activity of $4.8 \mathrm{nmol} \mathrm{Fe} \mathrm{n}^{2+}$-ferrozine formed $\mathrm{min}^{-1}$ (mg protein) $)^{-1}$ (Table 3).

Omission of the cofactor FMN from the assay mixture resulted in more than $70 \%$ decrease in the specific activity $\left[1.4 \mathrm{nmol} \mathrm{Fe}{ }^{2+}\right.$-ferrozine $\mathrm{min}^{-1}$ (mg protein) $\left.{ }^{-1}\right]$. Omis- 


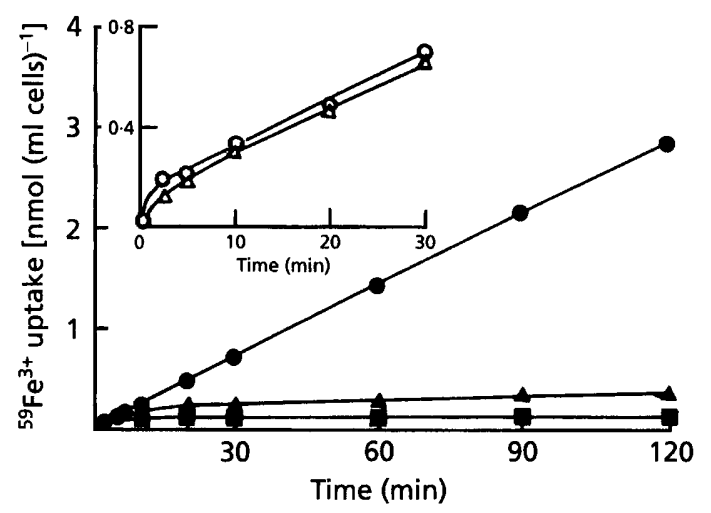

Fig. 4. Uptake of ${ }^{59} \mathrm{Fe}^{3+}$-siderophore complex by Rhizobium strain BICC 651 . Iron uptake by bacteria grown in medium containing succinate as the carbon source was measured in the presence $(\square)$ or absence of $(0) 50 \mu \mathrm{M} \mathrm{FeCl}_{3}$. The uptake buffer in $2 \mathrm{ml}$ volume contained sodium succinate and an iron-siderophore complex produced separately by incubating $20 \mathrm{nmol}{ }^{59} \mathrm{FeCl}_{3}$ with $200 \mathrm{nmol}$ purified siderophore. The curve for uptake of uncomplexed ${ }^{59} \mathrm{FeCl}_{3}$ by strain BICC 651 grown in the same medium in the absence of $\mathrm{FeCl}_{3}$ is also shown (A). Inset: iron uptake by strain BICC 651 grown in medium containing mannitol as the carbon source and in the absence of $\mathrm{FeCl}_{3}$. The uptake buffer contained ${ }^{59} \mathrm{Fe}^{3+}$-siderophore complex with mannitol $(O)$ or without any carbon source $(\triangle)$. The data shown are representative curves from replicate experiments.

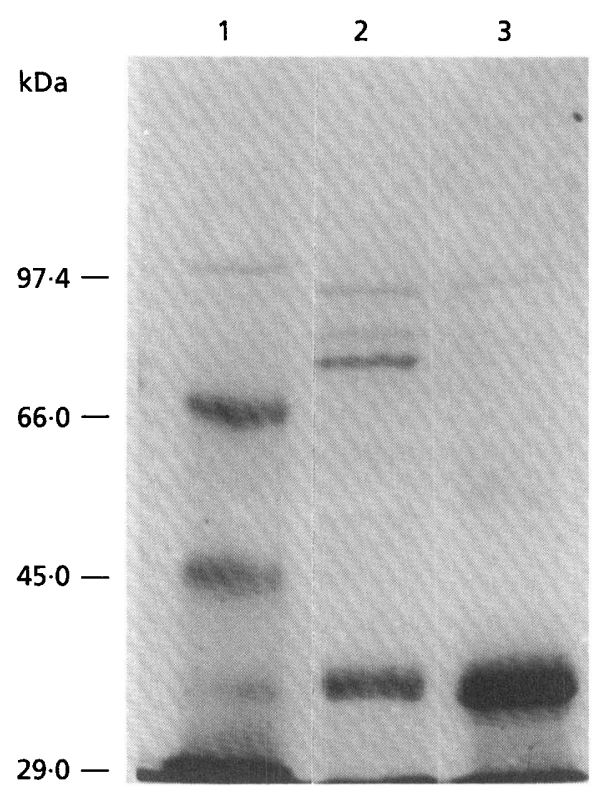

Fig. 5. SDS-PAGE profiles of the OM proteins of Rhizobium strain BICC 651. OM proteins were prepared by the Sarkosyl extraction method from cells grown in deferrated complete medium with $50 \mu \mathrm{M} \mathrm{FeCl}_{3}$ (lane 3) or with $0.5 \mu \mathrm{M} \mathrm{FeCl}_{3}$ (lane 2). Lane 1, molecular mass markers.

sion of $\mathrm{MgCl}_{2}$ from the assay mixture caused a decrease of only $23 \%$ in the specific activity. $\mathrm{Mg}^{2+}$ could be effectively replaced with $\mathrm{Ca}^{2+}$ but, relative to activity in the absence
Table 3. Activity and cation specificities of ferrireductase of Rhizobium strain BICC 651

Salts for corresponding cations were used at a concentration of $1 \mathrm{mM}$. The data shown are means of duplicate experiments.

\begin{tabular}{|lc|}
\hline Salt & Specific activity* \\
\hline $\mathrm{MgCl}_{2}$ & $4 \cdot 8$ \\
$\mathrm{MnCl}_{2}$ & $1 \cdot 4$ \\
$\mathrm{CaCl}_{2}$ & $4 \cdot 9$ \\
$\mathrm{CuSO}_{4}$ & $2 \cdot 6$ \\
$\mathrm{ZnSO}_{4}$ & $2 \cdot 1$ \\
$\mathrm{CoCl}_{2}$ & $0 \cdot 2$ \\
$\mathrm{NiCl}_{2}$ & $1 \cdot 5$ \\
$\mathrm{HgCl}_{2}$ & $0 \cdot 9$ \\
$\mathrm{SrCl}_{2}$ & $3 \cdot 2$ \\
$\mathrm{BaCl}_{2}$ & $3 \cdot 0$ \\
$\mathrm{Al}_{2}\left(\mathrm{SO}_{4}\right)_{3}$ & $4 \cdot 0$ \\
$\mathrm{NaCl}$ & $1 \cdot 1$ \\
$\mathrm{Control}$ & $3 \cdot 7$ \\
\hline
\end{tabular}

* Specific activity is expressed as $\mathrm{nmol} \mathrm{Fe}^{2+}$-ferrozine formed $\mathrm{min}^{-1}$ $(\mathrm{mg} \text { protein })^{-1}$. Deviation of the individual observations from the mean was $8 \%$ or less.

Table 4. Effect of different reductants on the activity of ferrireductase of Rhizobium strain BICC 651

Cytosolic fractions were treated with $40-80 \%$ saturation of $\left(\mathrm{NH}_{4}\right)_{2} \mathrm{SO}_{4}$ and the protein pellet obtained was used as the source of the enzyme. The data shown are means of duplicate experiments.

\begin{tabular}{|lc|}
\hline Reductant* & Specific activity $\dagger$ \\
\hline Ascorbate & $2 \cdot 1$ \\
Succinate & $1 \cdot 7$ \\
Reduced glutathione & $1 \cdot 4$ \\
NADH & $4 \cdot 8$ \\
NADPH & $4 \cdot 7$ \\
\hline
\end{tabular}

* All the reductants were used at a final concentration of $0.16 \mathrm{mM}$. $\dagger$ Specific activity is expressed as $\mathrm{nmol} \mathrm{Fe}^{2+}$-ferrozine formed $\mathrm{min}^{-1}$ $(\mathrm{mg} \text { protein })^{-1}$. Deviation of the individual observations from the mean was $11 \%$ or less.

of $\mathrm{Mg}^{2+}$, other metal ions were inhibitory to the activity (Table 3). NADPH was as effective as NADH as reductant while ascorbate, succinate or reduced glutathione were much less effective (Table 4). No enzyme activity was detectable in the absence of reductant.

The production of ferrireductase in Rbizobium strain BICC 651 appeared to be constitutive. DHBA was mixed in different proportions with a fixed amount of $\mathrm{FeCl}_{3}$ (DHBA: $\mathrm{FeCl}_{3}$ molar ratio $0: 1$ to $6: 1$ ) and incubated to allow complex formation. The incubation products were then used as substrate in enzyme assays. The highest activity of the enzyme occurred when $\mathrm{FeCl}_{3}$ was com- 
plexed with at least threefold higher DHBA concentration. Therefore, for the determination of the $K_{\mathrm{m}}$ of the enzyme, $\mathrm{FeCl}_{3}$ was complexed with a threefold excess of DHBA for use as the substrate. From the Lineweaver-Burk plot of the enzyme activities at different concentrations of the substrate, the $K_{\mathrm{m}}$ of the partially purified enzyme was determined to be $0.3 \mathrm{mM}$.

The enzyme was characterized by native PAGE to determine if it occurred as an isoenzyme. Enzyme activity was located in the presence of $4 \mathrm{mM}$ ferric citrate as substrate by an $\mathrm{Fe}^{2+}$-ferrozine staining procedure. Two isoenzymes were revealed by the activity staining. The $R_{F}$ values of the two isoenzymes were calculated to be 0.48 and 0.51 with respect to the bromophenol blue tracking dye (data not shown).

\section{DISCUSSION}

The results described here indicate that in deferrated complete medium not all strains of root nodule bacteria produce siderophores. This confirms the observation of Guerinot et al. (1990), who found that only one out of 20 strains of B. japonicum examined produced a siderophore. Our finding adds to the growing evidence that rhizobia, like other bacterial species, exhibit strain-to-strain variation in the ability to produce particular siderophores (Reigh \& O'Connell, 1988). However, the reason for the absence of detectable siderophore in the non-producing strains is unclear, for these bacteria possess an irondependent respiratory type of metabolism with an operative tricarboxylic acid cycle (Chakrabarti et al., 1987; Mandal \& Chakrabartty, 1993). The inability to detect siderophore production by some of the strains could be due to very low production. It appears that most of the bradyrhizobial strains lack siderophore-mediated iron acquisition systems, having evolved in the acid soils of the tropics where iron is more generally available than in neutral or alkaline soils (Guerinot et al., 1990).

Siderophores of root nodule bacteria represent a wide range of structures, including catecholates (Guerinot, 1991), hydroxamate (Carson et al., 1992), rhizobactin (Smith \& Neilands, 1984), anthranilic acid (Rioux et al., 1986a) and citric acid (Guerinot $e t$ al., 1990). The results in the present paper show that Rhizobium strain BICC 651 produced a siderophore which was identified as DHBA. This is the first report of release of DHBA under iron deficiency by a strain of Rbizobium isolated from $C$. arietinum, although strains of $R$. leguminosarum bv. trifolii (Skorupska et al., 1988) and R. leguminosarum bv. viciae (Patel et al., 1988) were reported to produce DHBA. Chemical assay indicated production of anthranilic acid, a siderophore structurally related to DHBA from a strain of R. leguminosarum bv. viciae (Rioux et al., 1986a), although some doubt was expressed by Rosendahl et al. (1991) about the reports of catechol siderophore production by Rbizobium. We identified the siderophore as DHBA by chromatographic comparison with reference compounds, analyses of UV and IR spectra and mass spectrometry. The siderophore contains threonine as its amino acid conjugate. The molecular ratio of the conjugate to DHBA was estimated to be close to two, indicating two threonine moieties, possibly as threonyl-threonine, linked to the $-\mathrm{COOH}$ group of the core compound, DHBA, by a peptide bond. Threonine was detected in siderophore of R. leguminosarum bv. viciae by Patel et al. (1988). Also, production of a catechol-like (DHBA) siderophore containing glycine and threonine by cowpea Rbizobium RA-1 was detected by Modi et al. (1985).

Rhizobium strain BICC 651, grown in medium where the available iron concentration was less than $0.3 \mu \mathrm{M}$, produced as much as $170 \mathrm{nmol}$ of the siderophore, based on DHBA content, during the late-exponential phase. As evidenced by a sharp decline in its level in the culture filtrate, the siderophore was either used up by the cells at a fast rate for iron acquisition or it became structurally modified or degraded and failed to react with the identifying reagents used. A small amount of iron was apparently required to stimulate optimum production of siderophore but the production was repressed by the presence of more than $50 \mu \mathrm{M}$ iron in the medium. Cells growing at $100 \mathrm{nM}$ iron secreted approximately 20 -fold more siderophore than those growing at $50 \mu \mathrm{M}$ ferric iron. Repression of rhizobial siderophore synthesis in the presence of iron in the growth medium was also observed by Skorupska et al. (1988). The higher accumulation of DHBA in iron-deficient, relative to iron-sufficient, cultures could result from a requirement of iron for the reaction catalysed by aminobenzoic acid decarboxylase.

Rbizobium strain BICC 651 is capable of growth in a large number of carbon sources including sugars, sugar alcohols and organic acids. Glucose, while generally a preferred carbon source, does not allow high siderophore production by strain BICC 651 . Growth on succinate and pyruvate, on the other hand, gives higher yields. Apparently, this is because succinate and pyruvate are metabolized through the tricarboxylic acid cycle, which requires an iron-containing system. As a consequence, the cells rapidly become depleted in iron resulting in higher production of the siderophore. Malate is a product of both arabinose and succinate metabolism and up to $3 \mathrm{mM}$ is produced during the late-exponential or early-stationary phase by all root nodule bacteria growing on arabinose and succinate (Carson et al., 1992). Malate, a C dicarboxylate, appeared to have no relationship with external iron concentration and did not support DHBA production by strain BICC 651.

The isolated siderophore can support iron nutrition of the homologous strain, thus demonstrating its biological property. Strain-specific utilization of siderophores in a Rhizobium species was first reported by Smith \& Neilands (1984). Siderophore-mediated competition for iron in microbial systems appears to be a widespread phenomenon and it therefore seems likely that in the rhizosphere, similar to Pseudomonas, a Rbizobium strain producing siderophore could outcompete a Rbizobium or any other micro-organism requiring iron but producing no siderophore (Kloepper et al., 1980). A Rbizobium strain capable of utilizing a siderophore produced by another strain of Rhizobium should also have a competitive advantage in the 
rhizosphere. In this paper we show that the strains BICC 632 and TAL 1012, both isolated from Cicer arietinum, could utilize the siderophore produced by Rbizobium BICC 651. Utilization of the same siderophore by different strains suggests that interstrain synergism may occur in the rhizosphere. On the other hand, antagonism among strains through the production of siderophore is also likely to occur in the rhizosphere and siderophore production, utilization and growth inhibition of other organisms by siderophore should play a role in competition (Reigh \& O'Connell, 1993). Rhizobium strain BICC 651 is an effective nitrogen-fixing strain and it profusely nodulates its host, which may be due to a selective advantage conferred by its siderophore production in the rhizosphere. However, further studies are needed to define strain dominance in the thizosphere, root nodulation and its association with siderophore production. It has been suggested that differences in nodule development under iron-deficient conditions may be due to varying abilities of different strains of root nodule bacteria to acquire iron for nodule initiation and development (O'Hara et al., 1988).

The transport of ferrisiderophore in Rhizobium strain BICC 651 appears to be similar to that of $R$. leguminosarum (Rioux et al., 1986b). During transport experiments more than $90 \%$ of added iron was still available for uptake by cells after $30 \mathrm{~min}$. In Escherichia coli transport of ferric citrate requires the products of the fec $A B C D E$ genes and functional ton $B$ and $e x b B$ genes (Pressler et al., 1988). These genes are negatively regulated by iron. Transport in strain BICC 651 may also require products of similar genes since cells grown in $50 \mu \mathrm{M} \mathrm{FeCl}_{3}$ transport very little ${ }^{59} \mathrm{Fe}^{3+}$. In the absence of siderophore, transport of free ${ }^{59} \mathrm{Fe}^{3+}$ is also low. These data indicate that the transport is inducible and siderophore-mediated as is observed in E. coli and Pseudomonas aeruginosa (Frost \& Rosenberg, 1973; Cox, 1980). With mannitol-grown cells the uptake of iron appeared to be biphasic, in contrast to succinate-grown cells. There was an initial rapid uptake followed by a slower rate of transport. Azotobacter vinelandii has also been reported to have a biphasic uptake of its own siderophores (Knosp et al., 1984). The rate of uptake of iron in both mannitol- and succinate-grown cells appeared to be similar in either the presence or absence of a carbon source in uptake medium. It is not certain if the uptake is an active process in strain BICC 651. Determining this will necessitate studying iron uptake by the cells in the presence of energy inhibitors (Carson et al., 1992). The reason why the uptake is biphasic in mannitol-grown cells in contrast to the monophasic uptake in succinate-grown cells has not been made clear in this study.

That the utilization of siderophore is due to the presence of a specific OM protein was demonstrated by comparing the OM profiles of Rbizobium strain BICC 651 grown in the presence or absence of iron. Two peptide bands of molecular mass 82 and $76 \mathrm{kDa}$ were expressed only under iron-deficient conditions; these could act as the receptor proteins for recognition of ferrisiderophore. Strong evidence of a receptor nature for such proteins was provided by the studies of Reigh \& O'Connell (1993) who compared the $\mathrm{OM}$ protein profiles of $\mathrm{R}$. meliloti strain 102F34::pGR30 with the profiles of $R$. meliloti strains 2011, 220-5 and 220-3. The strain 102F34::pGR30 produced a siderophore and could utilize the siderophores of the latter strains, whereas the parent strain R. meliloti 102 F34 did not produce a siderophore and could not utilize the siderophores of R. meliloti strains 2011, 220-5 and 220-3. In R. meliloti $102 \mathrm{~F} 34:: \mathrm{pGR} 30$ a $72 \mathrm{kDa}$ protein, which was not present in R. meliloti 102F34, was expressed only under low-iron conditions. The $72 \mathrm{kDa}$ protein was also induced in R. meliloti 2011, 220-5 and 220-3 under low iron conditions. Thus, in these strains, the $72 \mathrm{kDa}$ protein was the only receptor protein of the ferrisiderophore transport system.

The release of iron from its carrier is usually mediated by a ferrireductase. The enzyme reduces the $\mathrm{Fe}^{3+}$ of ferrisiderophore to $\mathrm{Fe}^{2+}$ which is then released. A ferrireductase was identified in soluble cell extract of Rbizobium strain BICC 651. This finding confirmed that ferrisiderophore was transported across the bacterial membrane before removal of iron. The enzyme was active under aerobic conditions as is the ferrireductase from Azotobacter vinelandii (Huyer \& Page, 1989). However, like most ferrireductases from other micro-organisms (Arceneaux, 1983), the creation of a partially anaerobic environment resulted in increased activity. This was also accompanied by an increased level of non-enzymic reduction of iron and the levels of enzymic activity varied widely. Since we were unable to resolve these problems, we therefore used conditions that were not strictly anaerobic. The activity of the ferrireductase from strain BICC 651 was not affected by the level of iron present in the growth medium; therefore, the enzyme appeared to be constitutive, unlike ferrireductase of certain fungi (Ernst \& Winkelmann, 1977).

The properties of the enzyme were similar to those recorded for other ferrireductases in that the enzyme required FMN as a cofactor and utilized either NADH or NADPH as a reductant. However, succinate, normally a good reductant for membrane-bound reductases, was not a good reductant for the reductase in Rbizobium strain BICC 651. The reaction of the enzyme was stimulated in the presence of magnesium while addition of other cations produced stimulation or was inhibitory as was also observed with the ferrireductase from Agrobacterium tumefaciens for the reduction of ferri-DHBA (Lodge $e t$ al., 1982).

From the activity staining in native gel, two forms of the enzyme were apparent, as was also found in Rhodopseudomonas sphaeroides (Moody \& Dailey, 1985) and in $P$. aeruginosa (Cox, 1980). Use of different concentrations of DHBA: $\mathrm{FeCl}_{3}$ (3:1) complex revealed that the semipurified enzyme ferrireductase from strain BICC 651 had an apparent $K_{\mathrm{m}}$ of $0.3 \mathrm{mM}$. The value appears to be high, considering that the $K_{\mathrm{m}}$ value of the enzyme of related organisms such as $P$. aeruginosa was $56 \mu \mathrm{M}$ for ferripyochelin although it was $303 \mu \mathrm{M}$ for ferric citrate and the organism had two enzymes for the two substrates (Cox, 
1980), from $A$. vinelandii the $K_{\mathrm{m}}$ was $10 \mu \mathrm{M}$ for ferric citrate (Huyer \& Page, 1989) and it was $8.3 \mu \mathrm{M}$, also for ferric citrate from $R h$. sphaeroides. However, the $K_{\mathrm{m}}$ value for the reductase for ferrischizokinen, the ferrisiderophore produced by Bacillus megaterium, a Gram-positive bacterium, was as high as $250 \mu \mathrm{M}$ (Arceneaux \& Byers, 1980). Of the two enzymes in $P$. aeruginosa, oxygen irreversibly inactivated the ferripyochelin iron reductase whereas the ferric citrate iron reductase with a high $K_{\mathrm{m}}$ was essentially unaffected by oxygen. The susceptibility of the two forms of ferrireductase observed in Rbizobium strain BICC 651 towards oxygen is not known. However, the high $K_{\mathrm{m}}$ of the enzyme for ferri-DHBA may be an indication of oxygen-sensitivity of a form of the enzyme.

The fact that the enzyme ferrireductase from strain BICC 651 uses ferrisiderophore as its substrate is indicative that it is used for iron assimilation. However, it would require isolation and studies of mutants of ferrisiderophore reductase of the strain for evidence that it is essential for iron transport by the siderophore system in vivo and that its function is to release the iron of ferrisiderophore for cell metabolism.

\section{ACKNOWLEDGEMENTS}

We are thankful to DIC (Bose Institute) for the use of typing facilities.

\section{REFERENCES}

Arceneaux, J. E. L. (1983). Ferrisiderophore reductases and iron assinilation. In Microbiology, 1983, pp. 288-292. Edited by D. Schlessinger. Washington, DC: American Society of Microbiology.

Arceneaux, J. E. \& Byers, B. R. (1980). Ferrisiderophore reductase activity in Bacillus megaterium. J Bacteriol 141, 715-721.

Arnow, L. E. (1937). Colorimetric determination of the components of 3,4-dihydroxyphenylalanine--tyrosine mixtures. J Biol Chem 118, 531537.

Bradford, M. M. (1976). A rapid and sensitive method for the quantitation of microgram quantities of protein utilizing the principle of protein-dye binding. Anal Biochem 72, 248-254.

Carson, K. C., Dilworth, M. J. \& Glenn, A. R. (1992). Siderophore production and iron transport in Rbizobium leguminosarum bv. viciae MNI: 710. J Plant Nutr 15, 2203-2226.

Cox, C. D. (1980). Iron uptake with ferripyochelin and ferric citrate by P'ieudomonas aeruginosa. J Bacteriol 142, 581-587.

Chakrabarti, S. K., Mishra, A. K. \& Chakrabartty, P. K. (1987). Cytochromes in free-living rhizobia. Curr Microbiol 15, 165-170.

Crichton, R. R. \& Charloteaux-Wauters, M. (1987). Iron transport and storage. Eur J Biochem 164, 485-506.

Csáky, T. Z. (1948). On the estimation of bound hydroxylamine in biological materials. Acta Chem Scand 2, 450 454.

Dailey, H. A., Jr \& Lascelles, J. (1977). Reduction of iron and synthesis of protoheme by Spirillum itersonii and other organisms. $J$ Bacteriol 129, 815-820.

Ernst, J. F. \& Winkelmann, G. (1977). Enzymatic release of iron from sideramines in fungi: $\mathrm{NADH}$ : sideramine oxidoreductase in Neurospora crassa. Biocbim Biophys Acta 500, 27-41.

Filip, C., Fletcher, G., Wulff, J. L. \& Earhart, C. F. (1973).
Solubilization of the cytoplasmic membrane of Escherichia coli by the ionic detergent sodium lauryl sarcosinate. J Bacteriol 115, 717-722.

Frost, G. E. \& Rosenberg, H. (1973). The inducible citratedependent iron transport system in Escherichia coli K12. Biocbim Biophys Acta 330, 90-101.

Guerinot, M. L. (1991). Iron uptake and metabolism in the Rhizobia/legume symbioses. In Iron Nutrition and Interactions in Plants, pp. 239-249. Edited by Y. Chen \& Y. Hadar. Netherlands: Kluwer Academic.

Guerinot, M. L., Meidl, E. J. \& Plessner, O. (1990). Citrate as a siderophore in Bradyrbizobium japonicum. J Bacteriol 172, 3298-3303.

Hathway, D. E. (1969). Plant phenols and tannins. In Chromatograpbic and Electrophoretic Tecbniques, pp. 308-354. New York: Interscience.

Huyer, M. \& Page, W. J. (1989). Ferric reductase activity in Azotobacter vinelandii and its inhibition by $\mathrm{Zn}^{2+}$. J Bacteriol 171, 4031-4037.

Kloepper, J. W., Leong, J., Teintze, M. \& Schroth, M. N. (1980). Enhanced plant growth by siderophores produced by plant growth promoting rhizobacteria. Nature 286, 885-886.

Knosp, O., von Tigerstorm, M. \& Page, W. J. (1984). Siderophoremediated uptake of iron in Azotobacter vinelandii. J Bacteriol 159, $341-347$.

Laemmli, U. K. (1970). Cleavage of structural proteins during the assembly of the head of bacteriophage T4. Nature 227, 680-685.

Lodge, J. S., Gaines, C. G., Arceneaux, J. E. L. \& Byers, B. R. (1982). Ferrisiderophore reductase activity in Agrobacterium tumefaciens. $J$ Bacteriol 149, 771-774.

Mandal, N. C. \& Chakrabartty, P. K. (1993). Succinate mediated catabolic repression of enzymes of glucose metabolism in rootnodule bacteria. Curr Microbiol 26, 247-251.

Markwell, M. A. K., Hass, S. M., Beiber, L. L. \& Tolbert, N. E. (1978). A modification of the Lowry procedure to simplify protein determination in membrane and lipoprotein samples. Anal Biochem 87, 206-210.

Modi, M., Shah, K. S. \& Modi, V. V. (1985). Isolation and characterization of catechol-like siderophore from cowpea $\mathrm{R} h i$ zobium RA-1. Arch Microbiol 141, 156-158.

Moody, M. D. \& Dailey, H. A. (1983). Aerobic ferrisiderophore reductase assay and activity stain for native polyacrylamide gels. Anal Biochem 134, 235-239.

Moody, M. D. \& Dailey, H. A. (1985). Ferric iron reductase of Rhodopseudomonas spbaeroides. J Bacteriol 163, 1120-1125.

Neilands, J. B. (1989). Siderophore systems of bacteria and fungi. In Metal Ions and Bacteria, pp. 141-163. Edited by T. J. Beveridge \& R. J. Doyle. New York: John Wiley \& Sons.

O'Hara, G. W., Hartzook, A., Bell, R. W. \& Loneragan, J. F. (1988). Response to Bradyrbizobium strain of peanut cultivars grown under iron stress. J Plant Nutr 11, 6-11.

Patel, H. N., Chakraborty, R. N. \& Desai, S. B. (1988). Isolation and partial characterization of phenolate siderophore from Rbizobium leguminosarum IARI 102. FEMS Microbiol Lett 56, 131-134.

Pressler, U., Staudenmaier, H., Zimmermann, L. \& Braun, V. (1988). Genetics of the iron dicitrate transport system of Eschericbia coli. J Bacteriol 170, 2716-2724.

Reigh, G. \& O'Connell, M. (1988). Siderophore production is strain specific in Rbizobium. In Nitrogen Fixation: Hundred Years After, pp. 826-839. Edited by H. Bothe, F. J. DeBruijn \& W. E. Newton. New York: Gustav Fischer.

Reigh, G. \& O'Connell, M. (1993). Siderophore-mediated iron transport correlates with the presence of specific iron-regulated 
proteins in the outer membrane of Rbizobium meliloti.J Bacteriol 175, 94-102.

Rioux, C. R., Jordan, D. C. \& Rattray, J. B. M. (1983). Colorimetric determination of catechol siderophores in microbial cultures. Anal Biochem 133, 163-169.

Rioux, C. R., Jordan, D. C. \& Rattray, J. B. M. (1986a). Iron requirement of Rbizobium leguminosarum and secretion of anthranilic acid during growth on an iron-deficient medium. Arch Biochem Biopbys 248, 175-182.

Rioux, C. R., Jordan, D. C. \& Rattray, J. B. M. (1986b), Anthranilate-promoted iron uptake in Rbizobium leguminosarum. Arch Biochem Biopbys 248, 183-189.

Rosenberg, H. (1979). Transport of iron into bacterial cells. Methods Enzymol 56, 388-394.

Rosendahl, L., Glenn, A. R. \& Dilworth, M. J. (1991). Organic and inorganic inputs into root nodule nitrogen fixation. In The Biology and Biocbemistry of Nitrogen Fixation, pp. 259-292. Edited by M. J. Dilworth \& A. R. Glenn. Amsterdam: Elsevier.

Schwyn, B. \& Neilands, J. B. (1987). Universal chemical assay for the detection and determination of siderophores. Anal Biochem 160 , $47-56$.

Silverstein, R. M., Bassler, G. C. \& Morrill, T. C. (1981). In Spectrometric Identification of Organic Compounds. New York: John Wiley and Sons.

Skorupska, A., Choma, A., Derylo, M. \& Lorkiewicz, Z. (1988). Siderophore containing 2,3-dihydroxybenzoic acid and threonine formed by Rbizobium trifolii. Acta Biocbim Pol 35, 119-130.

Smith, M. J. \& Neilands, J. B. (1984). Rhizobactin, a siderophore from Rbizobium meliloti. J Plant Nutr 7, 449-458.

Stookey, L. L. (1970). Ferrozine - a new spectrophotometric reagent for iron. Anal Chem 42, 779-781.

Vincent, J. M. (1970). A Manual for the Practical Study of the RootNodule Bacteria. I.B.P. Handbook no. 15. Oxford; Blackwell Scientific Publications.

Received 31 December 1993; revised 25 May 1994; accepted 13 June 1994. 